\title{
THE ELUSIVE SOBRALIA AMABILIS (ORCHIDACEAE): A RANGE EXTENSION OF ITS DISTRIBUTION TO ALTA VERAPAZ, GUATEMALA, WITH NOTES ON ITS HABITAT
}

\author{
Rafael Grajeda-Estrada ${ }^{1}$, Juan Pablo Rustrián-López ${ }^{1}$, \\ Marcelo José Serrano ${ }^{1}$, Andrés Villalobos-Soberanis ${ }^{1}$, Mayra L. Maldonado ${ }^{2,5}$, \\ María Renée Állvarez-Ruano ${ }^{3}$ \& Margaret A. Dix ${ }^{4}$
}
${ }^{1}$ Universidad del Valle de Guatemala, Facultad de Ciencias y Humanidades, Departamento de Biología 18 avenida $11-95$, zona 15 , Guatemala, Guatemala
${ }^{2}$ Proyectos Educativos Regionales de Autoayuda, Departamento de Investigación y Desarrollo, $6^{\mathrm{a}}$ avenida 8-25, zona 2, Guatemala, Guatemala
${ }^{3}$ Universidad del Valle de Guatemala, Centro de Estudios Ambientales y Biodiversidad, Herbario UVAL, edificio II2, 18 avenida 11-95, zona 15, Guatemala, Guatemala
${ }^{4}$ Universidad del Valle de Guatemala, Centro de Estudios Atitlán, Campus Altiplano, km 137, caserío Xolbé, cantón El Tablón, Sololá, Guatemala
${ }^{5}$ Author for correspondence: mmaldonado1975@yahoo.com

\begin{abstract}
We present a range extension for Sobralia amabilis, previously recorded from the southeastern border of Guatemala to Panama and Ecuador. Here, we detail its taxonomic history, description, and geographical distribution, along with photographs of the plants in vivo, habitat notes and recommendations for collecting and preparing herbarium specimens.

Resumen. Presentamos una extensión en el rango de distribución de Sobralia amabilis, la cual solo ha sido registrada desde la frontera suroriental de Guatemala hasta Panamá y Ecuador. Aquí se detalla su historia taxonómica, descripción y distribución geográfica, junto con fotografías de las plantas in vivo, notas sobre su hábitat y recomendaciones para colectar y preparar especímenes de herbario.
\end{abstract}

Key words / Palabras clave: América Central septentrional, bosque de neblina, cloud forest, Northern Central America, occurrence, ocurrencia, orchid, orquídea, Sobralieae

Introduction. The genus Sobralia Ruiz \& Pav. includes about 200 species native to the Neotropics (Baranow, Dudek \& Szlachetko 2017, Dressler, Acuña Zamora \& Pupulin 2016). These are known for their bamboo-like stem, with showy and ephemeral flowers that have taxonomic importance for discriminating sections and species (Brieger 1983). Dressler (2009) recognized the difficulty to classify sobralias by enumerating a few species complexes. The whole genus is noted for its lack of clarity in taxonomy and distribution, due mainly to intraspecific variation, and the difficulty of observing flowering plants in the field, because they are short-lived and have floral synchrony. Additionally, taxonomically informative herbarium specimens are hard to obtain, since the flowers deteriorate during the collection procedures (Baranow \& Szlachetko 2016, Dressler \& Bogarín 2007). In
Guatemala, about 14 Sobralia species have been generally accepted (CONAP 2019, Dix \& Dix 2000, WCSP 2019). Among these species, Sobralia amabilis (Rchb.f.) L.O.Williams has been classified under four synonyms in two genera since its discovery and description in 1852 (Reichenbach 1852, Reichenbach 1866, Schlechter 1923, WCSP 2019, Williams 1946, Williams 1956). Even in recent years, the need to improve the diagnostic characteristics among closely related species, S. amabilis (Rchb.f.) L.O.Williams, $S$. lepida Rchb.f. and $S$. wercklei (Schltr.) L.O.Williams has been brought up (Dressler 2003), and the lack of unified criteria in conspecific areas is obvious (Bogarín et al. 2014).

These species were first reported in northern Central America within a 44-year gap; Sobralia wercklei was first recorded in Honduras (Williams 1956), then as 


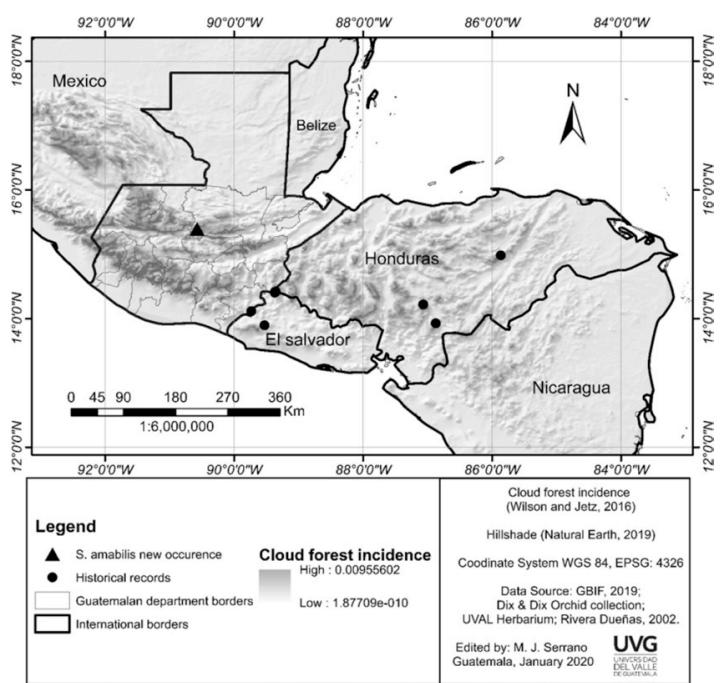

FIgURE 1. Sobralia amabilis reported localities in Guatemala, El Salvador and Honduras.

S. lepida in El Salvador (Hamer 1981), as S. amabilis and $S$. wercklei in El Salvador (Siegerist 1984), and S. amabilis in Guatemala (Dix \& Dix 2000). The Guatemalan specimen was registered near the summit of Volcán Chingo, above coffee plantations in broadleaf oak forest, close to the border with El Salvador. We know of no other citation for a locality in Guatemala. However, during an Ecological Assessment course field trip from Universidad del Valle de Guatemala, in June 2018, we collected S. amabilis (Fig. 1) on a private farm in western Alta Verapaz, Guatemala. This specimen represents a new location for the distribution of S. amabilis. Below, we detail its taxonomic history, description in vivo and specimen photographs, habitat notes, and recommendations for collecting Sobralia specimens.

\section{TAXONOMIC History}

Heinrich G. Reichenbach first described this orchid as Fregea amabilis Rchb.f. (1852: 712-713), from a specimen collected in Cordillera de Chiriquí, Panama, by Józef Warszewicz. Fourteen years later, Reichenbach described a similar orchid from Paso del Desengaño in Costa Rica and named it Sobralia lepida Rchb.f. (1866: 68). Later, Rudolf Schlechter described a new species, F. wercklei Schltr. (1923: 9), collected in San Jerónimo, Costa Rica, and distinguished it from $F$. amabilis for its greater height, broader leaves, and larger labellum. Then, Louis O. Williams (1946), while working on the Orchidaceae section of the Flora of Panama, determined that there are no differences between the genus Fregea Rchb.f. and Sobralia, so he included Fregea as a synonym of Sobralia, and he transferred $F$. amabilis to $S$. amabilis. Williams (1956), during the enumeration of the orchids of Central America, included S. amabilis, S. lepida and synonymized $F$. wercklei to $S$. wercklei, each one as a separate species. Right now, S. amabilis, S. lepida, and $S$. wercklei are not included in any of the Sections accepted for Sobralia (Dressler 2002).

\section{TAXONOMIC TREATMENT}

Sobralia amabilis (Rchb.f.) L.O.Williams, Ann. Missouri Bot. Gard. 33: 30. 1946.

SyNONYMS (WCSP 2019):

Sobralia lepida Rchb.f., Beitr. Orchid. -K. C. Amer: 68 (1866).

Fregea wercklei Schltr., Repert. Spec. Nov. Regni Veg. Beih. 19: 9 (1923).

Sobralia wercklei (Schltr.) L.O.Williams, Ceiba 5: 25 (1956).

Bas.: Fregea amabilis Rchb.f., Bot. Zeitung (Berlin) 10: 712-713. 1852. TYPE: Panama. Cordilleren von Chiriqui, J. Warszewicz s.n. (holotype, W).

Epiphytic herbs. Stem erect, cylindric, 10-30 $\mathrm{cm}$ long, $0.4 \mathrm{~cm}$ in diameter, covered with brownish sheaths, verrucose at the apex. Leaves up to 4, plicate, $4.33-11.10 \mathrm{~cm}$ long $\times 1.4-3.2 \mathrm{~cm}$ wide, lanceolate to long acuminate, strongly corrugated. Inflorescence brown or green bracts $3.4-5.0 \mathrm{~cm} \times 0.5-0.9 \mathrm{~cm}$, ellipsoid, verrucose, clustered, 1-2 flowers. Flowers 5-6 cm wide, color magenta, with a paler throat that has darker spots. Sepals elliptic to oblong or ovate, acute to apiculate, base connate; dorsal sepal $3.19 \times$ $1.24 \mathrm{~cm}$; lateral sepals $1.33 \times 2.95 \mathrm{~cm}$. Petals 2.97 $\times 1.24 \mathrm{~cm}$, elliptic or obovate, obtuse. Labellum 4.18 $\times 3.64 \mathrm{~cm}$, forming a basal tube $1.40 \times 0.49 \mathrm{~cm}$, covering the column, and extending abruptly into a flabellate-obovate, emarginated lamella, with wavy edges. Column 1.21-1.25 × 0.5-0.6 cm, white, slightly curved, apex dilated. Fruits and seeds not seen.

The characters measured are in the range of the data reported for S. amabilis (Archila et al. n.d., Dressler 

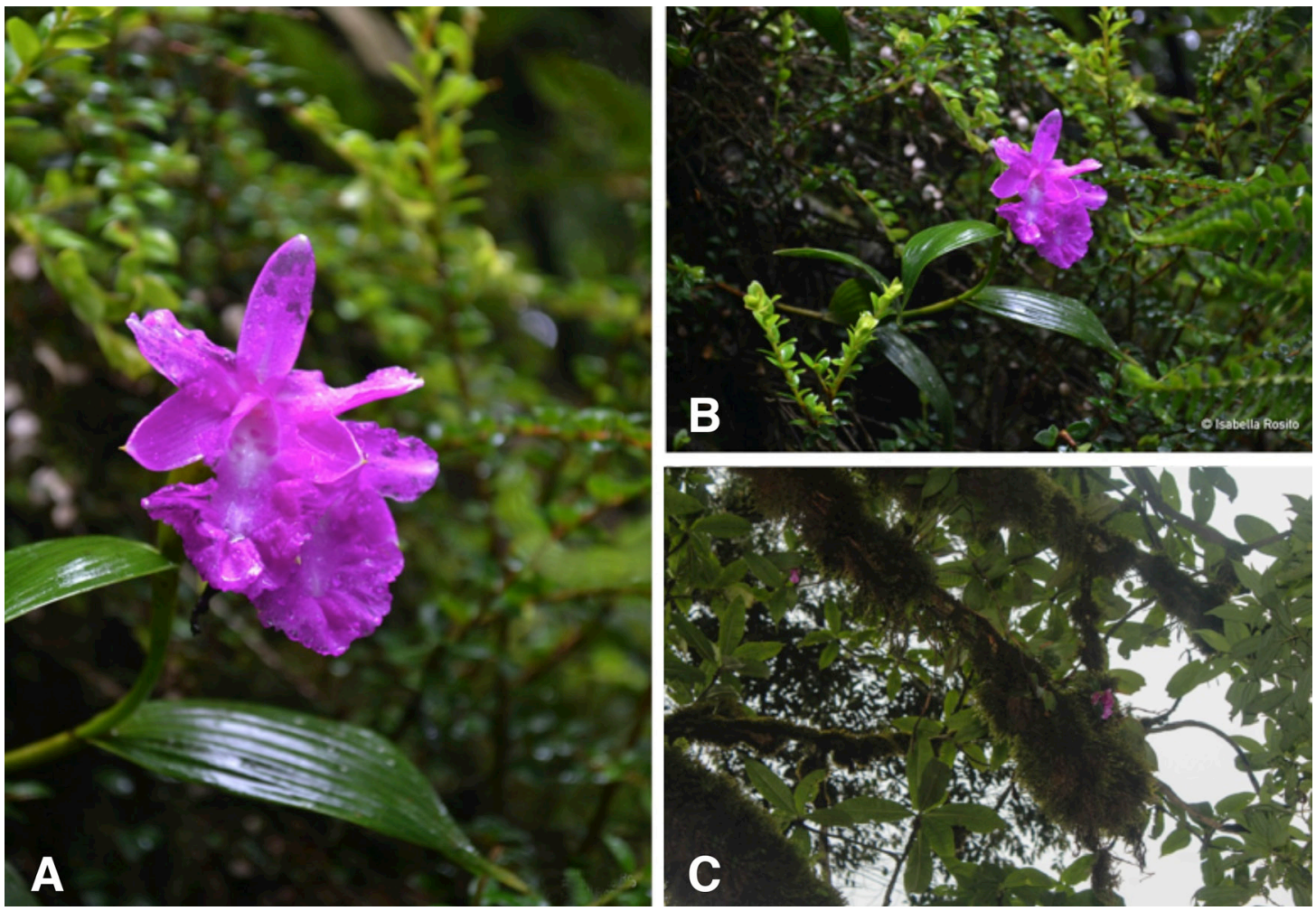

Figure 2. Sobralia amabilis, in situ A. Leaf and Flowers, close up. B. Whole plant. C. Habit. Photographs A \& B by Isabella Rosito; C by Rafael Grajeda-Estrada.

2003, Rivera-Dueñas 2002), except for the basal tube of the labellum ( $2 \mathrm{~mm}$ shorter), the sepals (10-20 mm wider), and column ( $2 \mathrm{~mm}$ longer). We also noticed that the dorsal sepal is slenderer than the lateral sepals, and we suggest keeping a separate record of these measurements.

Examined material. Guatemala. Alta Verapaz: San Cristóbal Verapaz, $2080 \mathrm{~m}$ elev., 3 June 2018, in bloom, collection project number $R$. Grajeda-Estrada et al. EER18c2 (Herbarium number UVAL-19920, dried collection) Figs. 1-2, 4

Distribution: Sobralia amabilis had been located from Ecuador to almost every country of Central America, except from Guatemala and Belize (Dressler 2003, GBIF.org 2019). Nevertheless, in 1991 Margaret and Michael Dix collected the species near the summit of Volcán Chingo, close to the border with El Salvador (Dix \& Dix 2000); however, the specimen is not available. Besides, there were no specimens in the herbarium of the Universidad del Valle de Guatemala (UVAL) and the Universidad de San Carlos de Guatemala herbaria: Herbarium of the Escuela de Biología (BIGU), Herbarium of the Centro de Estudios Conservacionistas (USCG) and Herbarium of the Facultad de Agronomía (AGUAT) (pers. obs.). Neither are records of $S$. amabilis or the related species, $S$. lepida and $S$. wercklei, from Guatemala at the free access database of the Global Biodiversity Information Facility (GBIF.org 2019).

Habitat and Ecology. The specimen comes from a flowering plant found in Northern Guatemala and corresponds to the northernmost occurrence of this species in Central America, about $168.57 \mathrm{~km}$ from the nearest locality previously registered at Volcán Chingo, Guatemala or $169.48 \mathrm{~km}$ from Trifinio, El Salvador (Fig. 1). Several epiphytic individuals of $S$. amabilis were found on a Hedyosmum mexicanum C.Cordem. (Chloranthaceae) tree, about 6 meters above ground (Fig. 2C) in a broadleaf, evergreen, tropical lower 


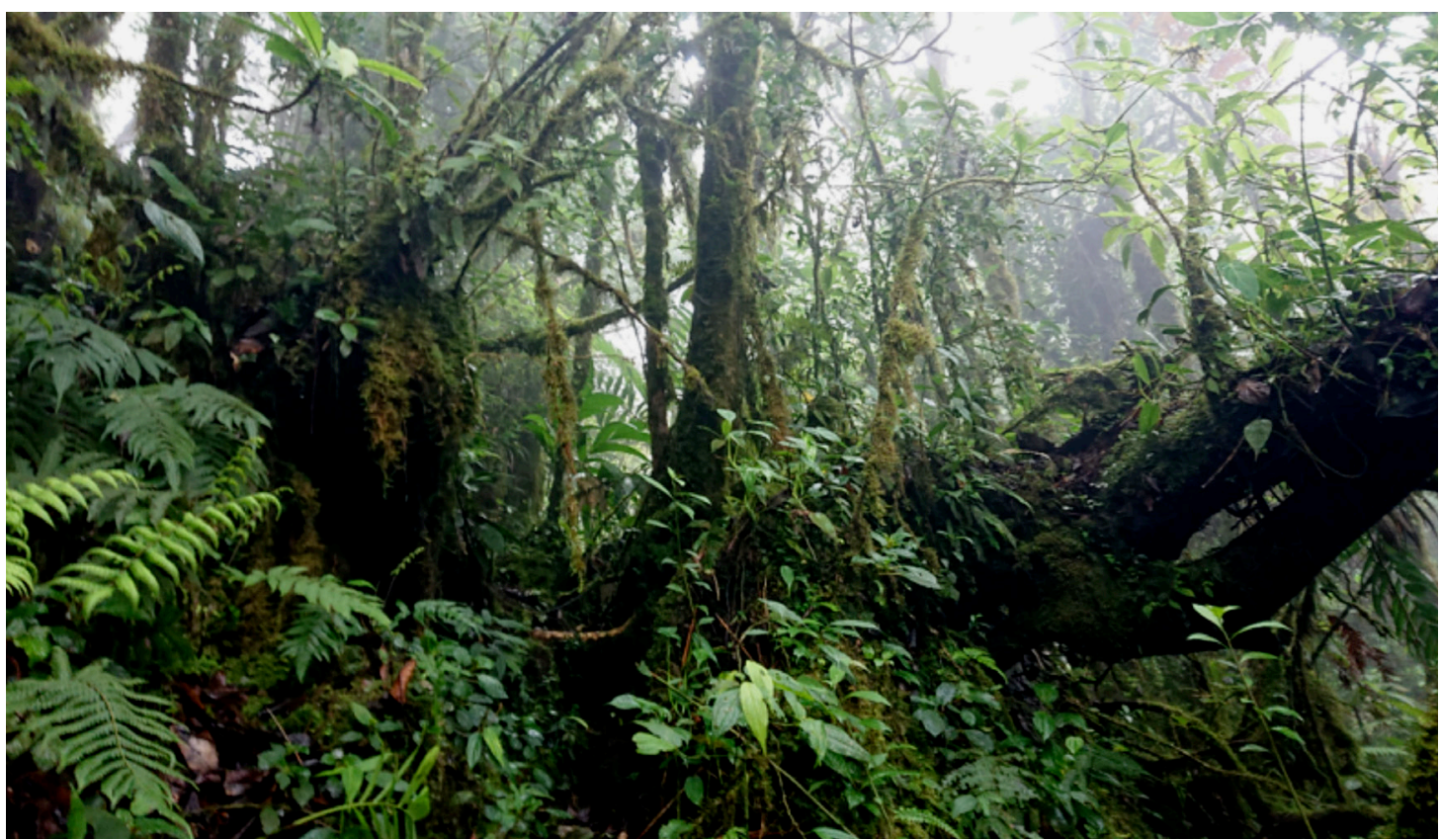

Figure 3. Habitat view at collection site, San Cristóbal Verapaz, Alta Verapaz, Guatemala. Photograph by Marcelo Serrano.
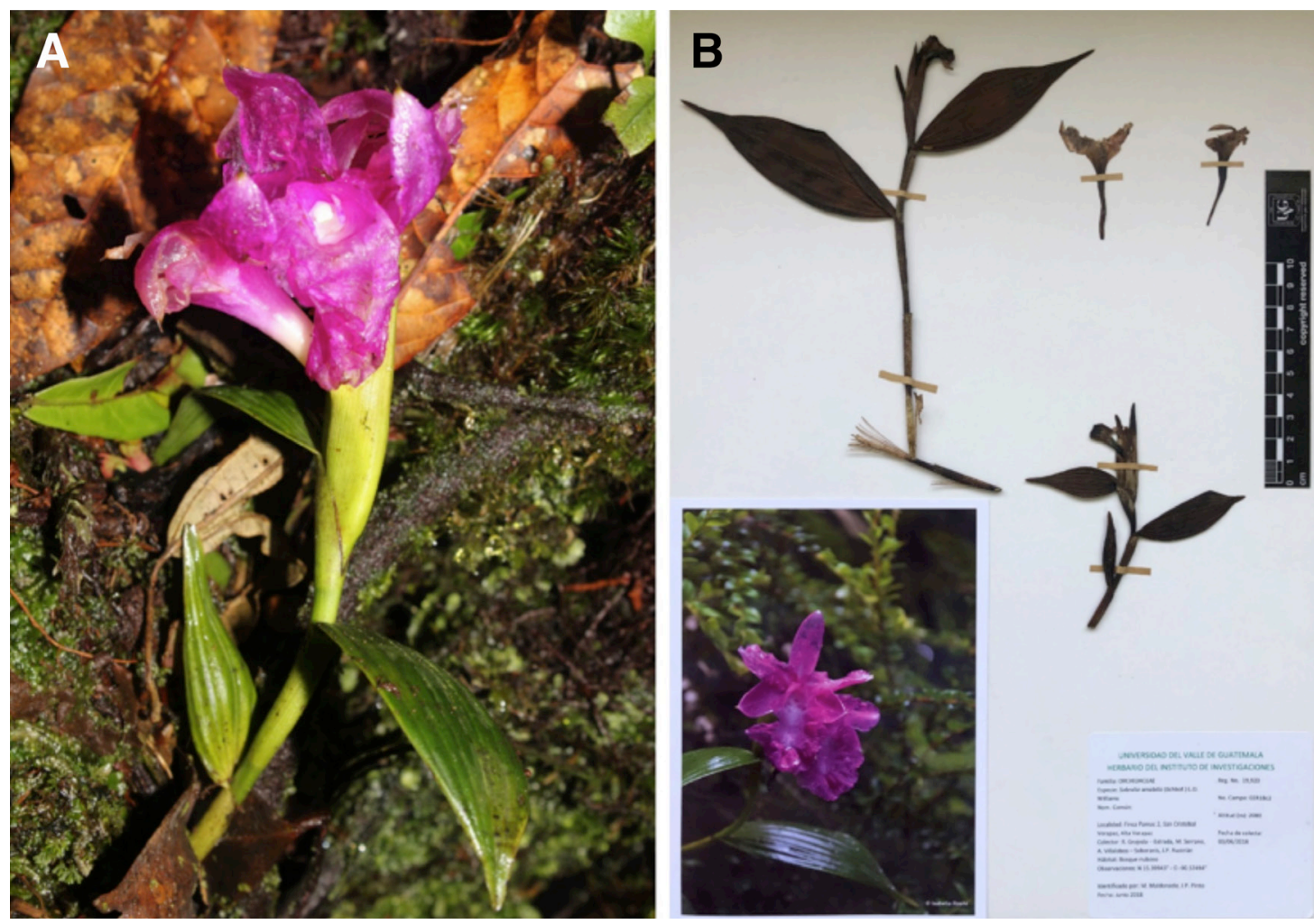

FiguRE 4. Collected specimen A. Before drying and pressing (R. Grajeda-Estrada et al. EER18c2). B. Herbarium specimen (UVAL-19920). Photographs by Rafael Grajeda-Estrada. 
montane wet forest on a private farm in San Cristóbal Verapaz, Alta Verapaz. The altitude range goes from 1700 to $2200 \mathrm{~m}$ elev., the average temperature is $16^{\circ} \mathrm{C}$; annual precipitation is $1946 \mathrm{~mm}$ (IARNA 2018). The evergreen forest includes trees like Alfaroa guatemalensis (Standl.) L.O.Williams \& Ant.Molina (Juglandaceae), Cojoba arborea (L.) Britton \& Rose (Leguminosae), Dendropanax arboreus (L.) Decne. \& Planch. (Araliaceae), Parathesis leptopa Lundell (Primulaceae), oaks (Fagaceae) like Quercus lancifolia Schltdl. \& Cham., and Q. conspersa Benth., arborescent ferns (Cyatheaceae) like Cyathea divergens Kunze and Alsophila tryoniana (G.J.Gastony) D.S.Conant. The understory includes shrubs like Miconia petiolaris (Schltdl. \& Cham.) Michelang. (Melastomaceae), small trees like Amphitecna montana L.O.Williams (Bignoniaceae) and several palms (Chamaedorea spp.). Also, there are various lianas (Ficus sp. (Moraceae) and Clusia sp. (Clusiaceae), epiphytic mosses, ferns, bromeliads and orchids (Fig. 3). So far, we have found 46 orchid species at the site.

Across its distributional range, Sobralia amabilis occurs in montane forests at elevations between $900 \mathrm{~m}$ to $3100 \mathrm{~m}$ like the Cordillera of Chiquirí, Panama and the Cordillera de Talamanca, Costa Rica. In Costa Rica, the orchid can be found on various volcanoes and natural reserves with lower montane rain forests (Bogarín et al. 2014, GBIF.org 2019, Monro et al. 2017, Pupulin 2010). Sobralia amabilis was reported at Volcán Mombacho, Granada, Nicaragua (GBIF.org 2019). There are reports of S. amabilis in the Reserva Biológica de Yuscarán in central Honduras, characterized by mountains and high annual precipitation (Rivera-Dueñas 2002). Also, in El Salvador, a plant of $S$. amabilis has been registered at the Parque Nacional Montecristo, part of Reserva de la Biosfera Trifinio, a tri-national reserve of the two previous countries and Guatemala established to preserve the Cerro Montecristo cloud forest (GBIF.org 2019, Hamer 1981). We describe the habitat of our recent find as a broadleaf cloud forest, with high epiphytes diversity, annual precipitation between $1600-4000 \mathrm{~mm}$ or more, from $20 \%$ to $60 \%$ of cloud coverage daily (Dix \& Dix 2018). Schuster et al. (2000), listed as cloud forests: the Sierras de las Minas, Santa Cruz, and Chamá; La Unión in Zacapa, and other localities in the mountains and volcanoes in southeastern Guatemala; these are found between the new site of occurrence and the one from Volcán Chingo, therefore there may be other populations of $S$. amabilis in these localities.

Recommendations. Collecting Sobralia specimens for dried preservation is difficult because the flowers of many species are fragile and tend to deteriorate quickly (Fig. 4), probably as a result of their ephemeral flowers and anatomy; even in spirit preservation, some material decays depending on the curation process (Dressler \& Bogarín 2007). Dressler (2002) suggests studying Sobralia using photographs and drawings based on living material from collections or field studies to achieve better documentation and understanding of the species, considering that the genus has been studied mainly on dried material (Baranow et al. 2017). Coinciding with Dressler (2002), we recommend collecting material in situ, immediately taking quality photographs with DSLR camera and an 18-55 mm f/3.5-5.6 lens. Also, the flowers should be preserved in a spirit collection with a solution of $75 \%$ ethanol, $5 \%$ glycerin and $20 \%$ distilled water to prevent deterioration; if there are more flowers available, at least one should be dissected and dry pressed to mount each floral part separately.

AcKNowledgments. Dedicated to the memory of Robert Louis Dressler, who worked tirelessly with neotropical orchids and contributed greatly to Sobralia research. We thank the Serrano family and especially Ruth Prem for their efforts to preserve their forest and for letting us explore the place; Juan Pablo Pinto, for his preliminary orchid identification in situ, and Isabella Rosito for her photographs. To the Universidad del Valle de Guatemala and Daniel Ariano for organizing the field trip during which this specimen was found; Diego Incer for facilitating the climatic data; CONAP for collection permit (A-003267). To the editors and both reviewers for their recommendations and improvement of this paper. Finally, to Michael W. Dix for sharing his love and knowledge about Guatemalan epiphytes.

\section{LiTERATURE CITED}

Archila, F., Szlachetko, D., Baranow, P. \& Chiron G. n.d. The genus Sobralia in Guatemala. Guatemalensis, 16(2), 9-10.

Baranow, P. \& Szlachetko, D. (2016). The taxonomic revision of Sobralia Ruiz \& Pav. (Orchidaceae) in the 
Guyanas (Guyana, Suriname, French Guiana). Plant Systematics and Evolution, 302(3), 333-355. doi: 10.1007/s00606-015-1266-2

Baranow, P., Dudek, M. \& Szlachetko, D. (2017). Brasolia, a new genus highlighted from Sobralia (Orchidaceae). Plant Systematics and Evolution, 303(7), 853-871. doi: 10.1007/s00606-017-1413-z

Bogarín, D., Serracín, Z., Samudio, Z., Rincón, R. \& Pupulin, F. (2014). An updated checklist of the Orchidaceae of Panama. Lankesteriana, 14(1), 135364. doi: 10.15517/lank.v14i3.17958

Brieger, F.G. (1983). Subtribus Sobraliinae. Lieferung, 13, $780-800$.

CONAP. (2019). Actualización de la Lista de Especies Amenazadas del Consejo Nacional de Áreas Protegidas: Orquídeas. Guatemala, Consejo Nacional de Áreas Protegidas, unpublished manuscript.

Dix, M. A., \& Dix, M. W. (2000). Orchids of Guatemala: A revised annotated checklist. St. Louis: Missouri Botanical Garden Press. 61 pp.

Dix, M. W., \& Dix, M. A. (2018). Bosques nubosos de Guatemala. In Monzón-Sierra, J., \& Dix, M.W. (Eds.), Reserva Natural Privada Refugio del Quetzal, Volcán Atitlán (pp. 26-29). Guatemala: Universidad del Valle de Guatemala.

Dressler, R. L. \& Bogarín, D. (2007). Two attractive new species of Sobralia from Panama. ORCHIDS, 76(9), 696-701.

Dressler, R. L (2002). The major sections or groups within Sobralia, with four new species from Panama and Costa Rica, S. crispissima, S. gloriana, S. mariannae and S. nutans. Lankesteriana, 5, 9-15. doi: 10.15517/ lank.v2i3.23088

Dressler, R. L. (2003). Orchidaceae. In Hammel, B.E., Grayum, M.H., Herrera, C. \& Zamora, N. eds. Manual de Plantas de Costa Rica (Vol. 3). Monocotiledóneas (Orchidaceae-Zingiberaceae). Missouri Botanical Garden Press, St. Louis, Missouri, United States. p 509.

Dressler, R. L. (2009). Can Sobralias be classified? The problems of identifying ephemeral flowers. ORCHIDS, 78(11), 658-663.

Dressler, R. L., Acuña Zamora, M.T. \& Pupulin, F. (2016). Sobralia turrialbina (Orchidaceae: Sobralieae): long cultivated and now described. Harvard Papers in Botany, 21(2), 251-261. doi: 10.3100/hpib. v21iss2.2016.n10

GBIF.org. (2019). GBIF Occurrence Download. doi: 10.15468(dl.s7rvau [Accessed 16 July 2018]

Hamer, F. (1981). Las Orquídeas de El Salvador III. United
States of America: Marie Selby Botanical Gardens. p. 224.

Instituto de Investigación y Proyección sobre Ambiente Natural y Sociedad -IARNA-. (2018). Ecosistemas de Guatemala basado en el sistema de clasificación de zonas de vida. Guatemala: Universidad Rafael Landívar. $122 \mathrm{pp}$.

Monro, A. K., Santamaría-Aguilar, D., González, F., Chacón, O., Solano, D., Rodríguez, A., Zamora, N., Fedele, E. \& Correa, M. (2017). A first checklist to the vascular plants of La Amistad International Park (PILA), Costa Rica-Panama. Phytotaxa, 332(1), 001283. doi: 10.11646/phytotaxa.322.1.1

Pupulin, F. (2010). Orchidaceae werckleanae: typification of Costa Rican orchid species described from collection by K. Wercklé. Botanical Journal of the Linnean Society, 163, 111-154. doi: 10.1111/j.1095-8339.2010.01051.x

Reichenbach, H. G. (1852). Neue Orchideen der Expedition des Herrn J. de Warszewicz. Botanische Zeitung, 10, $712-713$.

Reichenbach, H. G. (1866). Beitrage zu einer Orchideenkunde Central-Amerika's. Hamburg: Meissner. p 10-11, 105, Tab. 2.

Rivera-Dueñas, R. A. (2002). Guía ilustrada de 55 especies de Orquideas encontradas en la Reserva Biológica de Yuscarán, Honduras. Honduras: Zamorano. Thesis. 84 pp.

Schlechter, R. (1923). Beiträge zur Orchideenkunde von Zentralamerika: II Additamenta ad Orchideologiam Costaricensem. Repertorium Specierum Novarum Regni Vegetabilis. Beihefte, 19, 9.

Schuster, J. C., Cano, E. B. \& Boucher, S. (2000). Un método sencillo para priorizar la conservación de los bosques nubosos de Guatemala, usando Passalidae (Coleoptera) como organismos indicadores. Acta Zoológica Mexicana (n.s.), 80, 197-209.

Siegerist, E. S. (1984). Herbarium specimens of the Orchidaceae of Central America - a checklist. Selbyana, 7, 281-311.

WCSP. (2019). World Checklist of Selected Plant Families. Facilitated by the Royal Botanic Gardens, Kew. Published on the Internet; http://wcsp.science.kew.org/ [Accessed 18 July 2018]

Williams, L. O. (1946). Flora of Panama. Part III Fascicle II: Orchidaceae. Annals of the Missouri Botanical Garden, 33(1), 30.

Williams, L. O. (1956). An enumeration of Orchidaceae of Central America, British Honduras and Panama. CEIBA, 5(1), 22-23, 25. 